\title{
THE EUROPEAN CHARTER FOR EQUALITY OF WOMEN AND MEN IN LOCAL LIFE AS A TOOL FOR INCREASING THE REPRESENTATION OF WOMEN IN THE REPRESENTATIVE BODIES OF LOCAL AND REGIONAL SELF-GOVERNMENT
}

\author{
Sanda Pašuld, LLM, PhD Candidate \\ Josip Juraj Strossmayer University of Osijek, Faculty of Law \\ Stjepana Radića 13, Osijek, Croatia/Gajev trg 3/I, Osijek, Croatia \\ sandapasuld@gmail.com
}

\begin{abstract}
The European Charter for Equality of Women and Men in Local Life (2006) was first presented at the $\sigma^{\text {th }}$ Council of Europe's European Ministerial Conference and at the meeting of the Committee on Women's Rights and Gender Equality of the European Parliament in 2006 as an extension of the "Cities for Equality" initiative of the Council of European Municipalities and Regions (CEMR). Adoption and active application of the principles and rules of the above-mentioned European Charter are the foundation of the political and social life at a local level. Furthermore, they are of utmost importance for promoting equality of women and encouraging their stronger political engagement in order to achieve true gender equality. By the end of 2018, only 27 local and regional self-government units signed the European Charter in the Republic of Croatia, three of which were municipalities, twelve cities and twelve counties. The representation of women in representative bodies of local and regional government is extremely low in the Republic of Croatia, and the society's lack of interest in any changes aimed at greater participation of women in the political life of the state is evident. This serious state of affairs first and foremost necessitates local and regional self-governments adopting the European Charter, which provides clear guidelines for the implementation of the principles of equality of women and men at the local level, and strengthens the participation of women in the political life of the local community and beyond. Although little has been written about the European Charter in scholarly and professional papers, it is a platform which can be upgraded with a number of positive actions for raising the awareness of the local public, with a view to a more effective implementation of the principle of gender equality in all areas of local community life: political, economic, social and cultural.
\end{abstract}

Keywords: European Charter for Equality between Women and Men, political rights of women, local and regional self-government, human rights

\section{INTRODUCTION}

Despite all efforts invested by the United Nations, the European Union, the Council of Europe and other relevant international and regional organizations 
as well as specialized agencies, the inequality of women and men is still exists not only in undeveloped democratic states, but also in democratic states or the states in transition to democracy. Inequality of women and men is present in all spheres of social, political, economic and cultural life, and it is particularly evident in political life at all levels of government. As local and regional authorities are in the position to take concrete steps towards achieving equality between women and men, they are the possibility to bring about an increase in political representation of women quickly and easily.

It is the responsibility of local and regional authorities to regulate and manage the affairs within the legal framework and in the interest of the local population, and to develop the best solutions to improve the quality of life. Promoting the right to equality and greater participation of women in the development and implementation of public policies at the local and regional level of government will contribute to the creation of a society founded on equality.

The European Charter for Equality of Women and Men in Local Life (hereinafter: the European Charter) is one of the documents with the purpose to change the low ratio of women compared to men in social life at the local level as well as to raise awareness in the society of the importance of these changes. The Preamble of the European Charter sets forth that local and regional self-government units, as signatories to the Charter, are committed to following the principles of equality between women and men and to fulfilling the obligations in the areas of their responsibility laid down in the European Charter by an adapted action plan for equality, in which every local and regional self-government unit determines its priorities, activities and resources intended for this purpose. ${ }^{1}$ By developing an action plan for equality and linking the signatories with relevant institutions at national, European and international level to promote gender equality, it supports the implementation of the European Charter and serve an example to other local and regional self-government units for its adoption.

It is worth noting in the very introduction that the translation of the European Charter into the Croatian language poses a problem, since there are two different "official translations". One translation can be found on the official website of the Government of the Republic of Croatia and the other on the official web pages of CEMR itself. The Section IV of the paper deals with differences in the translation and the problems arising therefrom in more detail.

The European Charter for Equality of Women and Men in Local Life, Council of European Municipalities and Regions, CEMR's General Assembly, Innsbruck, 2006 
Gender equality is one of the fundamental principles of international law proclaimed in a series of international treaties and in most national legislations. Nonetheless, in the Republic of Croatia, true equality of women and men in everyday life, including political life, has not been achieved. Section II of this paper briefly and generally describes the position of women in politics. The international and national regulations of Croatian legislation governing the principle of gender equality in the field of political participation are listed in Section III. Section IV is an overview of the European Charter with a more elaborate reference to Article 2, which obliges the signatories to develop the area of a political role through political representation. The results of the research into women representation in representative bodies of local and regional self-government in the Republic of Croatia for the last four electoral districts of the local elections are presented in the next section. The research was conducted with an aim to determine the accomplishment of gender equality principle implementation by providing an overview of women and men representation in local and regional self-government bodies. The results of the above-mentioned election rounds that it is necessary to change the current situation and to increase the number of women in the representative bodies of local and regional self-government are drawn as a conclusion in Section VI.

The underlying hypothesis is that women in the representative bodies of local and regional self-government in the Republic of Croatia are under-represented and that no significant changes have taken place in this respect for the last three electoral rounds. In order to determine the state of representation of women and men in this paper, the method of statistical data analysis has been applied. The results of the data analysis show that the change in the current state of affairs in this respect requires new tools. The author starts from the hypothesis that the low level of representation of women in the representative bodies of local and regional self-government in the Republic of Croatia can be increased by implementation of the European Charter as a platform that can be upgraded by a number of positive actions, which will raise public awareness of the issue. Although there are a number of signatories to the European Charter in the Republic of Croatia, it has not yet fully developed into practice and additional efforts are needed to recognize and implement it as an effective tool for achieving gender equality.

\section{POSITION OF WOMEN IN POLITICS WITH SPECIAL REFERENCE TO THE REPUBLIC OF CROATIA}

In spite of adoption of new laws and policies in many countries, examples of good practice and support measures, underrepresentation of women in public and political life has still remained a critical issue undermining the full functioning 
of democratic institutions and processes. ${ }^{2}$ Political activity and public decisionmaking are areas with male predominance. ${ }^{3}$ Thus, during the $20^{\text {th }}$ century, efforts were made to correct this "pyramidal rule", and especially optimistic expectations aroused in the initial phase of democratic changes in transition countries and in the Republic of Croatia, as well. ${ }^{4}$ In contemporary developed democracies, the issue of gender equality is slowly coming to the focus of attention, and it may be said that underrepresentation of women in politics has been gradually recognized as a feature of an unhealthy democracy and a deep crisis of political representation. ${ }^{5}$ The unfavourable position of women in political representation is considered injustice that must be corrected by diverse measures, anti-discrimination laws and positive actions. ${ }^{6}$ In order to achieve equal opportunities for all, without barriers to economic, social and political participation based on gender, women need a certain means of protection as one of the measures of positive discrimination, which can be provided in the form of quotas. ${ }^{7}$

Electoral quotas are measures of equal opportunities requiring that the electionnominating bodies, which in most political systems are allocated to political parties, recruit, nominate or elect more women to political functions, and are, therefore, considered as a fast track towards achieving equal representation of women and men in politics. ${ }^{8}$ Today, parliamentary democracies are obviously committed to equality of women and men in political decision-making as a prerequisite to true democracy; however, this proves not to be easily accomplished, even in cases where there is a social consensus on this.?

The reasons for under-representation of women in politics are numerous. Most authors divide the factors not favouring female political participation into three

2 Gender Equality Strategy 2018-2023, [https://www.coe.int/en/web/genderequality/gender-equality-strategy/] Accessed 15.04.2019

3 Ibid.

4 Leinert Novosel, S., Žena na pragu 21. stoljeća - između majčinstva i profesije, TOD and EDAC, Zagreb, 1999

5 Sineau, M., Ravnopravnost - Vijeće Europe i sudjelovanje žena u političkom životu, Vijeće Europe, 2003

$6 \quad$ Suk, J.C., Gender Quotas after End of Men, Boston University Law Review, Vol. 93, 2013, pp. 11231139

7 Sawer, M., Equal opportunities, in: Kramarae; Cheris/Spender (eds.), International Encyclopaedia of Women. Global Women Issues and Knowledge, Dale: Routledge, London/New York, 2000

8 Dahlerup, D., Women, Quotas and Politics, Routledge research in comparative politics, Routledge, London and New York, 2006

9 Leinert Novosel, S., Politika ravnopravnosti spolova: kako do „kritične mase“ žena u parlamentima?, Politička misao, Vol. XLIV, 2007, No 3, pp. 85-102 
groups: political, socio-economic and socio-cultural. ${ }^{10}$ Main reasons listed in contemporary literature are electoral systems, the way in which political parties operate, gender stereotypes, roles and values transferred by some family models, as well as a social and private division of work leaving little room for participation of women in public and political life. ${ }^{11}$ The above-listed reasons intertwine; however, one reason stands out in the context of this paper, and that is the way in which the political parties operate. Namely, the process of nominating a candidate may be different in political parties, it may be conducted in specific circumstances depending on how centralised the process itself is and how important the objective or subjective attributes of the aspirant(s) are; but the final result always remains the same - the candidate nomination procedure is controlled exclusively by political parties. ${ }^{12}$ As the general issue of underrepresentation of women in politics is an extensive topic reaching beyond the scope of this paper, due to the length limitation of the paper, the reader is referred to consult a wealth of additional scholarly and professional sources. ${ }^{13}$

The issue of underrepresentation of women in politics has certainly been related to the Republic of Croatia since its independence at all levels of political decisionmaking, as well. ${ }^{14}$ Since 1945 women in the Republic of Croatia have active and

10 Šinko, M. Žene u parlamentima - globalna perspektiva, Politička misao, Vol. XLIV, No 2, 2007, pp. 71-92

11 See: Shvedova, N. Obstacles to Women's Participation in Parliament, in Women in Parliament: Beyond Numbers, International IDEA, Stockholm, 2005, p. 44; Norris, P., Passages to Power: Legislative Recruitment in Advanced Democracies, Introduction; Theories of recruitment, Cambridge University Press, Cambridge, 1997; Kenworthy, L., Malami, M., Gender Inequality in Political Representation: A Worldwide Comparative Analysis, The University of North Carolina Press, Social Forces, September 1999, Vol. 78, No. 1, pp. 235-269; Lovenduski, J., State Feminism and Political Representation, Cambridge University Press, 2005

12 Kunovich, S., Paxton, P., Pathways to Power: The Role of Political Parties in Women's National Political Representation, American Journal of Sociology, Vol. 111, No 2, 2005, pp. 505-552

13 Tremblay, M., Women and Legislative Representation: Electoral Systems, Political Parties and Sex Quotas, Palgrave Macmillan, 2012; Sawer, M., Tremblay, M., Trimble, L., Representing Women in Parliament: A Comparative Study; Diaz, M.M., Representing Women?: Female Legislators in West European Parliaments, ECPR Press, 2005; Ortenblad, A., Marling, R., Vasiljevic, S., Gender Equality in a Global Perspective, Routledge, 2017; Hayes, D., Lawless, J.L., Women on the Run: Gender, Media, and Political Campaigns in a Polarized Era, Cambridge University Press, 2016; Norris, P., Electoral Engineering, Voting, Rules and Political Behaviour, Cambridge, Cambridge University Press, 2004; Freedman, J., Women in the European Parliament, in: Women, Politics and Change, Oxford University Press, New York, 2002; Hughes, M.M., Intersectionality, Quotas and Minority Women's Political Representation Worldwide, The American Political Science Review, Vol. 105, 2011, pp. 604-620; Paxton, P., Hughes, M.M., Painter, M.A.II., Growth in Women's Political Representation: A Longitudinal Exploration of Democracy, Electoral System and Gender Quotas, Center for the Study of Democracy, UC Irvine, 2009; Mansbridge, J., Quota Problems: Combating the Dangers of Essentialism, in: Politics \& Gender 1, No 4, 2005, pp. 369-398

14 Leinert Novosel, S., Percepcija, iskustvo i stavovi o rodnoj (ne)ravnopravnosti u politici, in: Rodna ravnopravnost i diskriminacija u Hrvatskoj, Istraživanje "Percepcija, iskustva i stavovi o rodnoj diskriminaci- 
passive voting rights, that is, they can vote for and be elected in all political bodies, but even today their actual representation in political life is persistently, with slight exceptions, very weak. The statistical data published by the Central Bureau of Statistics on the topic Women and Men in Croatia indicate this. ${ }^{15}$ The statistical indicators show the position of women and men in the Republic of Croatia in the areas of population, health, education, employment and wages, pension insurance, judiciary and political authorities based on the annual survey conducted by the Central Bureau of Statistics. ${ }^{16}$ Statistical data indicating that women make up $51.5 \%$ of the total population in the Republic of Croatia and that they are underrepresented in politics and economy, which means that they are rarely employed and professionally advancing has been used as a starting point for drafting the bill of the first Gender Equality Act in the Republic of Croatia. ${ }^{17}$ Although institutional regulations in the Republic of Croatia, as analysed later on in the paper, allow women to engage in politics, most political parties have no genuine strategy for involving women in their political work. In such conditions, women can hardly obtain a passing position at electoral slates, and they remain marginalized and politically underrepresented.

In recent Croatian political practice, most parties that are not guided by the principle of gender equality, position women on the bottom of electoral slates. These positions are not transitory, and, consequently, women could not be elected to the representative bodies of local and regional self-government. This leads to the conclusion that the implementation of the meaning and purpose of the balanced gender participation principle to be applied on electoral slates, as laid down by the law, has been evaded. If political parties really want to achieve a balanced representation of both sexes in representative bodies and thus achieve the full purpose of rules governing gender equality issue, then, they should ensure that positive measures are implemented, which will then result in equal representation of both sexes in representative bodies. This could be achieved by applying the alternate male and female candidates' position on electoral slates, the so-called zipper system. ${ }^{18}$ In addition, political inequality may be avoided by regularly raising public

ji u Republici Hrvatskoj“, Zagreb, Biblioteka ONA, 2011, pp. 185-209

15 The publication Žene i muškarci u Hrvatskoj has been published as a yearbook since 2006 by the Central Bureau of Statistics. It contains important consolidated and updated statistical data on status of women and men in the Republic of Croatia

16 See in: Leinert Novosel, S., Rodni stereotipi, predrasude i diskriminacija žena u politici, Ljudska prava žena, Institut društvenih znanosti Ivo Pilar, Zagreb, 2011, pp. 113-126

17 Rodin, S.; Vasiljević, S., Zakon o ravnopravnosti spolova, Revija za socijalnu politiku, Vol. 10, No. 3, 2003, pp. 397-402

18 The definition of zipper system was given by: Vandenbeld, A., International Trends in Women's Political Participation, The Oxford Handbook of Transnational Feminist Movements, Oxford University Press, 
awareness about equality between women and men, as well as by encouraging political parties to put women to winning positions in election slates, i.e. at the top of the slate.

\section{LEGISLATIVE PROVISIONS AND POLICIES AS REGARDS EQUALITY OF WOMEN AND MEN IN THE FIELD OF POLITICAL ACTIVITIES IN THE REPUBLIC OF CROATIA}

This section gives an overview of existing international, European and national legal regulations and policies related to political equality of women and men. General legal act with the highest legal status in the Republic of Croatia - the Constitution of the Republic of Croatia ${ }^{19}$, guarantees the principle of equality in its two basic forms: equality before the law and as a ban on discrimination against certain characteristics, the list of which is not exhausted. ${ }^{20}$ Article 14 of the Constitution of the Republic of Croatia in Chapter III stipulates the general clause of equality before the law defining the protection of human rights and fundamental freedoms. Thus, every person in the Republic of Croatia is granted enjoyment of rights and freedoms regardless of race, colour, sex, language, religion, political or other opinion, national or social origin, property, birth, education, social status or other features. These normative guarantees should be distinguished from moral requirement for the achievement of fundamental values, as in Art. 3 of the Constitution of the Republic of Croatia, which identifies gender equality as one of the fundamental values of the constitutional order, defines it in a substantive sense, sets the regulatory goal of exercising equality, and forms a constitutional basis for application of the principle of equal opportunities as an exception to the principle of formal equality in Art. 14 of the Constitution of the Republic of Croatia. ${ }^{21}$ International treaties are regulations constituent to the internal legal order of the Republic of Croatia. Referring to their importance, Article 141 of the Constitution of the Republic of Croatia stipulates as follows: "International treaties concluded and ratified in accordance with the Constitution of the Republic of Croatia, and made public, and which are in force shall be part of the internal legal order of the Republic of Croatia and shall be above legislation in terms of legal effects." There-

2015, p. 231; Sledzinska-Simon, A., Genders Quotas and Women Solidarity as a Challenge to the Gender Regime in Poland, in: Lepinard, E.; Rubio-Marin, R. (eds.), Transforming Gender Citizenship, Cambridge University Press 2018, p. 262

19 Constitution of the Republic of Croatia, Official Gazette 56/1990, 135/1997, 8/1998, 113/2000, 124/2000, 28/2001, 41/2001, 55/2001, 76/2010, 85/2010, 05/2014

20 Gardašević, Đ., Ljudska prava i temeljne slobode u Ustavu RH, in: Ljudska prava, Pravni fakultet Sveučilišta u Zagrebu, Zagreb, 2014, pp. 51-61

21 Rodin, S., Jednakost muškarca i žene, Pravo i politika u EU i Hrvatskoj, Institut za međunarodne odnose - IMO, Zagreb, 2003, p. 5 
fore, all international treaties that are ratified by the Republic of Croatia and in force are in terms of legal value above the national legislation.

There is a whole range of international instruments referring to women's rights, and the Republic of Croatia is a party to these instruments. In addition to the Charter of the United Nations (1979) ${ }^{22}$, there are some other important instruments regarding women's political rights. Firstly, there is the Convention on the Political Rights of Women (1952) ${ }^{23}$, International Covenant on Civil and Political Rights (1966) ${ }^{24}$, International Covenant on Economic, Social and Cultural Rights $(1966)^{25}$, Declaration on the Elimination of Discrimination against Women $(1967)^{26}$, Convention on the Elimination of All Forms of Discrimination Against Women (1979) ${ }^{27}$, Declaration on the Elimination of Violence Against Women $(1993)^{28}$, Beijing Declaration and Platform for Action (1995) ${ }^{29}$, Optional Protocol to the Convention on the Elimination of All Forms of Discrimination against Women $(1999)^{30}$, Millennium Declaration $(2000)^{31}$, and the 2030 Agenda for Sustainable Development (2015). ${ }^{32}$

22 Povelja Ujedinjenih naroda, Official Gazette - International Agreements No 15/1993 and 7/1994

23 Konvencija o političkim pravima žena, Službeni list FNRJ, Međunarodni ugovori i drugi sporazumi, No 7/1954; the Republic of Croatia is a party to this Convention according to the Decision on publishing of multilateral treaties that the Republic of Croatia is a signatory to based on the succession notification, Official Gazette - International Agreements, No 12/1993

24 Međunarodni pakt o građanskim i političkim pravima, Službeni list SFRJ, No 7/1971; the Republic of Croatia is a party to this Covenant according to the Decision on publishing of multilateral treaties that the Republic of Croatia is a signatory to based on the succession notification, Official Gazette International Agreements, No 12/1993

25 Međunarodni pakt o ekonomskim, socijalnim i kulturnim pravima, Službeni list SFRJ, No 7/1971; the Republic of Croatia is a party to this Covenant according to the Decision on publishing of multilateral treaties that the Republic of Croatia is a signatory to based on the succession notification, Official Gazette - International Agreements, No 12/1993

26 Declaration on the Elimination of Discrimination against Women, Resolution adopted by the UN General Assembly 2263 (XXII), 7 November 1967

27 Konvencija o uklanjanju svih oblika diskriminacije protiv žena, Službeni list SFRJ, Međunarodni ugovori No 11/1981; the Republic of Croatia is a party to this Covenant according to the Decision on publishing of multilateral treaties that the Republic of Croatia is a signatory to based on the succession notification, Official Gazette - International Agreements, No 12/1993

28 Declaration on the Elimination of Violence against Women, A/RES/48/104, Resolution adopted by the UN General Assembly on 20 December 1993

29 Beijing Declaration and Platform for Action, the Fourth World Conference on Women Beijing Declaration, September 1995, UN Women, United Nations 1995

30 Fakultativni protokol uz Konvenciju o eliminaciji svih oblika diskriminacije protiv žena, Official Gazette - International Agreements, No 3/2001 and 4/2001

31 United Nations Millennium Declaration, A/RES/55/2, Resolution adopted by the UN General Assembly on 8 September 2000

32 The 2030 Agenda for Sustainable Development, A/RES/70/1, Resolution adopted by the UN General Assembly on 25 September 2015 
It is assumed today that the Council of Europe as the oldest European international organisation has a decisive role in the area of human rights protection. Equality of women and men as well as (political) women's rights are at the heart of human rights protection and the Council of Europe, which has passed a wide and complex network of regulations, standards, guidelines and policies to achieve true gender equality in the Member States. In this context, the following conventions are considered key documents: the Convention for the Protection of Human Rights and Fundamental Freedoms (1950) with Protocols no. 1, 4, 6, 7, 12, 13 and $14^{33}$, the European Social Charter $(1961)^{34}$, the Council of Europe Convention on Action against Trafficking in Human Beings (2005) ${ }^{35}$, the Council of Europe Convention on the Protection of Children against Sexual Exploitation and Sexual Abuse (Lanzarote Convention, 2007) ${ }^{36}$, and the Council of Europe Convention on Preventing and Combating Violence against Women and Domestic Violence (Istanbul Convention, 2011). ${ }^{37}$

By accession of the Republic of Croatia to the European Union, the European law has been given supremacy over national law. ${ }^{38}$ The development of the European Union did not originally aim at protection of human rights and fundamental freedoms, hence the founding treaties do not comprise provisions on fundamental rights and freedoms, since the original aims of all three (since 2002 of two) European Communities were economic in nature, and market-integration oriented. ${ }^{39}$ However, the European Union is founded, inter alia, on the values that promote equality of women and men. A wide range of bodies has been active and cooperating in the area of legislation adoption and promotion of equality, fighting discriminatory policies and practices. These are primarily the European Commission, the

33 Konvencija za zaštitu ljudskih prava i temeljnih sloboda i Protokoli No 1, 4, 6, 7, 12, 13 and 14, Official Gazette - International Agreements, No 18/1997, 61/1999, 8/1999, 14/2002, 13/2003, 9/2005, $1 / 2006$ and $2 / 2010$

34 Europska socijalna povelja, Official Gazette - International Agreements, No 15/2002 and 8/2003

35 Konvencija Vijeća Europe o suzbijanju trgovanja ljudima, Official Gazette - International Agreements, No $7 / 2007$

36 Konvencija Vijeća Europe o zaštiti djece od seksualnog iskorištavanja i seksualnog zlostavljanja, Official Gazette - International Agreements, No 11/2011

37 Konvencija Vijeća Europe o sprječavanju i borbi protiv nasilja nad ženama i obiteljskog nasilja, Official Gazette - International Agreements, No 3/2018

38 See more on this subject in the decision of the Court of Justice of the European Union setting the basis for the principle of supremacy of EU law over national laws by reasoning that the Community constitutes a new legal order of international law for the benefit of which the States have limited their sovereign rights and the subjects of which comprise both states and their nationals ECR 13: Van Gend en Loos, Case 26/62, 1963

39 Omejec, J., Vijeće Europe i Europska Unija, Institucionalni i pravni okvir, Novi informator, Zagreb, 2008, p. 228 
Council and the European Parliament. The European Union's anti-discrimination law has started with the provisions on equal pay for men and women and for work of equal value, in which, besides founding treaties, the secondary legislation had a special role in the European legal framework. As early as 1976, the European Union (then the EEC) adopted numerous guidelines as secondary sources of gender equality law. The first legislation in this reference was Directive 75/117 (1975) on equal pay, followed by Directive $76 / 207$ on equal access to employment, vocational training, promotion and working conditions (1976.), and then Directive $79 / 7$ on the principles of equal treatment in matters of social security (1978.), etc. ${ }^{40} \mathrm{~A}$ full overview of the primary legislation, contractual provisions, directives, policies, initiatives, recommendations, conclusions and achievements of the EU in the area of gender equality and non-discrimination, as well as a survey of the progress in the case law of the Court of Justice of the European Union are not the topic of the paper due to the amount of documents and the size limitation of the paper. ${ }^{41}$

For the last two decades, the Republic of Croatia has strengthened the fundamental institutional mechanisms and introduced important changes in legislation with a view to preventing gender discrimination and promoting equal opportunities policy. ${ }^{42}$ A network of regulations governing the issue of equality between women and men has been created, and in the context of this paper and in relation to the issue of political equality of women and men, the most important are the Political Parties Act $(1993)^{43}$, Act on Election of Representatives to the Croatian Parliament $(1999)^{44}$, Gender Equality Act $(2008)^{45}$, Anti-Discrimination Act $(2008)^{46}$, and the Act on Local Elections (2012) ${ }^{47}$.

The Political Parties Act improves special measures by granting a 10\% funding bonus (Art. 19, para. 4) to the parliamentary parties for each female representative, i.e. for underrepresented sex. Political equality of women and men is governed by

40 See in: Craig, P., de Burca, G., EU Law, Text, Cases and Materials, Fifth edition, Oxford, University press, 2011, pp. 873-874

${ }^{41}$ See in: Vasiljević, S., Slično i različito - Diskriminacija u Europskoj uniji i Republici Hrvatskoj, TIMpress, Zagreb, 2011

42 Vasiljević, S., Neka se čuje i druga strana: primjeri spolne i etničke diskriminacije, Centar za ženske studije, Zagreb, 2012

43 Zakon o političkim strankama, Official Gazette, 76/1993, 111/1996, 164/1998, 36/2001, 28/2006

44 Zakon o izboru zastupnika u Hrvatski Sabor, Official Gazette, 116/1999, 109/2000, 53/2003, 69/2003, 167/2003, 44/2006, 19/2007, 20/2009,145/2010, 24/2011, 93/2011,120/2011, 19/2015, $104 / 2015$

45 Zakon o ravnopravnosti spolova, Official Gazette, 82/2008, 69/2017

46 Zakon o suzbijanju diskriminacije, Official Gazette, 85/2008, 112/2012

47 Zakon o lokalnim izborima, Official Gazette,144/2012, 121/2016 
the Act on Election of Representatives to the Croatian Parliament, which regulates the election of MPs to the Croatian Parliament and their nomination. The candidate application procedure is summarized in Article 20 para. 3 of the Act, which stipulates that political parties independently determine their party lists and the order of candidates, in the manner laid down in the statute of the political party, or in accordance with special statutory decisions. The Act on Local Elections (Article 9 paragraph 3) obliges political parties as proponents of the slates to observe the principle of gender equality, in accordance with a special law (which would be the Gender Equality Act). The current 2008 Gender Equality Act replaced the former 2003 Gender Equality Act ${ }^{48}$ by introducing new and better solutions. The general provisions of this Act define the policy of equal opportunities by setting forth the general grounds for the protection and promotion of gender equality as the fundamental value of the constitutional order of the Republic of Croatia. Moreover, it defines and regulates the ways of protection against gender discrimination as well as the creation of equal opportunities for women and men (Article 1). Further provisions of this Act define gender equality by determination that women and men are equally present in all areas of public and private life, have equal status, equal opportunities to exercise all rights, as well as the same benefit of the results achieved (Article 5). The Act also introduces special measures in the form of quotas for elimination of gender inequality in cases where representation of one gender in political and public decision-making bodies is lower than $40 \%$ (Articles 9 and 12). The relevant law in this context is the Anti-Discrimination Act. The general provisions of this Act in Art. 1 provide for the protection and promotion of equality as the highest value of the constitutional order of the Republic of Croatia, create the preconditions for achieving equal opportunities, and regulate protection against discrimination based on racial or ethnic origin or colour, gender, language, religion, political or other belief, social background, property status, trade union membership, education, social status, marital or family status, age, health condition, disability, genetic heritage, gender identity, expression or sexual orientation.

In addition to the above-mentioned network of regulations, the Republic of Croatia has also set up a significant institutional protection with an aim to prevent gender discrimination and promote equal opportunities policy. The Gender Equality Committee of the Croatian Parliament has been established ${ }^{49}$ as a working

\footnotetext{
48 Zakon o ravnopravnosti spolova (Official Gazette 116/2003) was passed on 14 July 2003 by the Croatian Parliament and it expired on 15 July 2008

49 See the official web site of the Gender Equality Committee of the Croatian Parliament (Odbor za ravnopravnost spolova Hrvatskog sabora), [https://ravnopravnost.gov.hr/institucionalni-mehanizmi-1639/odbor-za-ravnopravnost-spolova-hrvatskoga-sabora/2021/] Accessed 05.04.2019
} 
body dealing with issues of gender equality. For conducting professional affairs, the Government of the Republic of Croatia has established the Gender Equality Office, whose scope of work is determined by the Gender Equality Office Ordinance $^{50}$ and the Gender Equality Act (2008). Additionally, pursuant to Article 19 of the Gender Equality Act, the institution of the gender equality ombudsperson has bas established as an independent body for fighting gender-based inequality or discrimination. The basic task of this Office is to monitor the implementation of the Gender Equality Act and other regulations related to gender equality. Articles 27 and 28 of this Act stipulate that gender equality coordinators are appointed in state administration bodies, that commissions for gender equality may be established in the local and regional self-government units, and that city and municipal commissions must be established as operating advisory bodies of county assemblies for the areas of regional self-government with the task of promoting gender equality at a local level.

The Croatian Government and the Croatian Parliament adopt national strategic plans for activities with the purpose of implementing the Gender Equality Act (2008), in accordance with Article 18, paragraph 2, item 4, and aiming at eliminating discrimination against women and establishing true gender equality by implementing a policy of equal opportunities. The first plan of this kind was the National Policy for the Promotion of Equality adopted in 1997, followed by the National Policy for the Promotion of Gender Equality 2001-2005, adopted in 2001, and later by the National Policy for the Promotion of Gender Equality of 2006 for the period from 2006 to 2010, and finally the National Policy for Gender Equality 2011-2015 51 adopted in 2011. Since 2015 no new strategic document has been drafted. In 2017 the report on the work of the Gender Equality Office of the Government of the Republic of Croatia argued that the document of National Policy for the period after 2015 had not been issued due to extraordinary elections for the Croatian Parliament held in 2016 and formation of the new Government of the Republic of Croatia. ${ }^{52}$ The Working Group for drafting National Policy has been set up in 2015, but its composition was changed at the time of the 2017 elections. The result of these sequence of events is that for four years there has not been any strategy for achieving gender equality in Croatia and that there are still

50 Uredba o uredu za ravnopravnost spolova, Official Gazette, 39/2012

51 See in: Nacionalna politika za promicanje ravnopravnosti spolova za razdoblje 2001-2005, Official Gazette 112/2001, Nacionalna politika za promicanje ravnopravnosti spolova za razdoblje 2006-2010, Official Gazette 114/2006, Nacionalna politika za promicanje ravnopravnosti spolova za razdoblje 2011-2015, Official Gazette 88/2011

52 See the official web site of the Government of the Republic of Croatia (Vlada RH), Izvješće o radu Ureda za ravnopravnost spolova Vlade RH u 2017, [https://vlada.gov.hr/UserDocsImages//2016/Sjednice/2018/11\%20studeni/125\%20sjednica\%20vRH//125\%20-\%2029.pdf] Accessed 05.04.2019 
no signs when and for what period a new national gender equality policy will be adopted, which is essential to achieving effective gender equality.

\section{EUROPEAN CHARTER FOR EQUALITY OF WOMEN AND MEN IN LOCAL LIFE}

The European Charter was adopted in 2006 by the Council of European Municipalities and Regions (CEMR), which is the largest organization of local and regional authorities in Europe. It is the extension of the project "The City for Equality" funded by the European Commission since 2004 and drafted by the CEMR with examples of good practices in local communities, with a view to establishing a methodology for achieving equality in local communities. ${ }^{53}$ The CEMR comprises 60 member associations from 41 out of 47 member states of the Council of Europe, including all 28 member states of the European Union. In total, they represent just over 150,000 municipalities and regions. ${ }^{54}$ By the end of 2018, only 1736 signatories from 35 countries, or slightly over 1\% of the CEMR members of the municipalities and regions, adopted the European Charter. ${ }^{55} \mathrm{At}$ the beginning of this section there are two problems that need to be pointed out. Firstly, the problem of unconsolidated official translations of the European Charter into the Croatian language. There are two official translations and they differ for basic terminology. The first translation was done by the Local Democracy Agency from Mostar (2012) published as a complete text of the European Charter in the Croatian language on the official website of the Council of Municipalities and Regions (CEMR). ${ }^{56}$ The second translation is on the official web site of the Gender Equality Office of the Government of the Republic of Croatia, without any indication of the author. ${ }^{57}$ The differences in these translations start with the very title of the document. The first translation of the European Charter reads as Europska povelja o ravnopravnosti spolova na lokalnoj razini (the European Charter

53 The Cities for Equality project is a virtual city designed as a model of enabling the local authorities to improve the conditions for the gender equality achievement. Retrieved from: [http://www.charter-equality.eu/the-charter/la-presidence-en.html/] Accessed 15.04.2019

54 See official web site of Observatory European Charter for Equality of Women and Men in Local life, [http://www.charter-equality.eu/atlas-of-signatories-of-the-charter/presentation.html/] Accessed 12.04.2019

55 Ibid.

56 Europska povelja o ravnopravnosti spolova na lokalnoj razini, Mostar, 2012, [http://www.charter-equality.eu/wp-content/uploads/2013/03/European-Charter-in-Croatian-HR2. pdf/] Accessed 05.04.2019

57 Europska povelja za ravnopravnost žena i muškaraca na lokalnoj razini, [https://ravnopravnost. gov.hr/institucionalni-mehanizmi-1639/europska-povelja-o-ravnopravnosti-zena-i-muskaraca-na-lokalnoj-razini/3088/] Accessed 15.04.2019 
on Gender Equality at the Local Level), and the second translation reads as Europska povelja za ravnopravnost žena $i$ muškaraca na lokalnoj razini (the European Charter on Equality of Women and Men in Local Life). Furthermore, the terminology of these two translations into Croatian is different. In "the Mostar translation", the original term women and men was shortened to gender, unlike "the Zagreb translation" and the original text of the European Charter in the English language (compare: Principle 2, Principle 6, Article 4 paragraph 2, Article 11 paragraph 1, Article 12 paragraphs 1 and 2 of the European Charter). However, comparison of the original text of the European Charter in English with both translations in Croatian reveals that neither of the two mentioned translations into the Croatian language is satisfactory. In other words, in both Croatian translations, the word gender has been translated as spol (sex) although the correct translation would be rod (gender) ${ }^{58}$, and the term gender equality has been translated as ravnopravnost spolova (sex equality), although the correct translation is rodna ravnopravnost (gender equality) $)^{59}$. In Croatian public sphere the term rod (gender) as a concept has caused considerable controversies, and has generated public discussions on differences between the terms spol (sex) and rod (gender) in the society when the term rod (gender) has often been put into a negative context, especially by the conservative section of the society. The mindset of the Croatian society is mainly traditional and there are certain social circles that contradict the concept of rod (gender) and do not accept it either as an idea or as a legal term. All this has obviously resulted in the tendency to avoid the term rod (gender) in the translations of the European Charter into the Croatian language.

Another problem is in reference to the fact that in many verified databases there are no scholarly or professional papers dealing with the topic of the text and the scope of the European Charter as a mechanism for increasing equality of women and men in local communities. All things considered, there is not only a lack of interest in accepting the European Charter in practice, but that there is a lack of interest, as the above data show, in the theory as well to solve the issue of gender inequality (at a local level). The author concludes that the weak public presentation of the European Charter, i.e. its presentation before the bodies of local and regional authorities that would have to be committed to it, led to the insufficient use of the Charter as a tool that did not encourage scientific research.

The European Charter is an instrument of political commitment of local authorities. It has been drafted as a clear guide for local authorities on undertaking actions

58 See Article 2 paragraph 5, Article 2 paragraph 6, Article 8 paragraph 1, Article 14 paragraph 3 item 3, Article 15 paragraph 2 item 2

59 See Article 4 paragraph 1 item 3, Article 12 paragraph 3 item b), e) and f), Article 27 paragraph 3 item 2, Article 30 paragraph 2 item 3 
within their competences. ${ }^{60}$ By signing it, the local authorities encourage policies and concrete measures aimed at achieving gender equality at the local level, in cooperation with relevant local, national, European and international institutions and organizations. Apart from promoting gender equality and equal opportunities policy, the European Charter primarily sets out assessing the gender-impact of gender-based decisions and policies by local authorities. The Charter is divided into three parts. The first part establishes the principles, the second part deals with implementation modalities of the Charter and its commitments, whereas the third part comprises thirty articles governing different areas elaborated by detailed action plans for achieving equality. This allows the signatories to select the areas that are priority for them, useful and feasible as their implementation tasks. It follows from the foregoing considerations that it is better to select a smaller number of clear, but achievable areas of action in the plan of action for equality than a large number of areas that cannot be achieved, and consequently will not lead to a targeted change. According to Part III of the European Charter, the activities in selected areas can be elaborated upon issues of democratic accountability, political role, general framework for equality, regulation of the role of employer, public procurement and contracts, role of service provision, planning and sustainable development. In relation to the political role of women, Article 2 of the European Charter regulates the issue of political representation by proclaiming the principle of balanced representation and recognizes equal rights for women and men; thus the paper analyses the application of this article in local communities in the Republic of Croatia. The implementation of Article 2 paragraph 1 recognizing the equal suffrage for women and men, to be a candidate for and to hold elected office for citizens in the Republic of Croatia does not seem too complicated, since general and equal suffrage (both active and passive) for both women and men is clearly guaranteed by Article 45 of the Constitution of the Republic of Croatia. Furthermore, the signatories to the European Charter recognize in Article 2 paragraph 2 equal rights of women and men to participate in the formulation and implementation of policies, to hold public office and to perform all public functions at all levels of government. This part of the task leaves no doubt and does not create any difficulties in implementation. However, paragraph 3 of Article 2 of the European Charter committing a local or regional self-government unit to recognize the principle of balanced representation in all elected and public decision-making bodies will be the most difficult task and it will be crucial in drafting the action plan for equality for the signatories to the Charter in the Republic of Croatia.

60 See more on local self-government competences in: Chandler, J.A., Local Government Today, Third edition, Manchester University Press, 2001, pp. 100-116 
The measures that the signatory should take in order to uphold the above mentioned rights and principles pursuant to Article 2 of the European Charter are called reasonable measures and they propose to encourage women to apply for entry into the registry of voters, to exercise their suffrage and to be candidate for public service. It also promotes the encouragement of political parties to adopt and enforce the principle of balanced representation of women and men and, if necessary, to issue quotas in order to increase the number of electoral female candidates or elected female representatives. Furthermore, the signatories are committed to regulating their own procedures and standards of conduct so that potential female candidates and elected female representatives are not discouraged by stereotypes in behavior and speech i.e. harassment as well as adoption of measures to enable elected female representatives / male representatives to harmonize their private, business and public lives. All aforementioned measures are praiseworthy and welcomed, and it is up to the local communities to clarify their implementation. Due to their general definition, there is a possibility that bodies in local communities developing equality action plans interpret them differently or adapt them according to their needs.

Namely, local and regional community policy is established in their representative bodies: city councils and county assemblies. City councils and county assemblies are, pursuant to Article 27 of the Law on Local and Regional Self-Government ${ }^{61}$, defined as the citizens' representative bodies that pass the acts within the scope of the functions of the local or regional self-government units. Thus, they represent places where decisions on all important issues and local community policies are made. Therefore, the local communities will have to take important measures for ensuring the implementation of the task referred to in Article 2 of the European Charter in order to advance the balance between the representation of women and men in political representation.

As stated in Section III of this paper, the Local Elections Act (2012) obliges political parties to comply with the principle of gender equality as slate proponents in accordance with the Gender Equality Act (2008). The ultimate goal of the latter is to achieve, in reference to equal participation of women and men in authorities at all levels of government (Article 12), to reach the level of representation of both sexes according to their share in the total population in the Republic of Croatia, which is why special measures - quotas have been considered. However, as the results of this research paper show, the quotas as special measures require additional support, that can be found in Article 2 of the European Charter. There-

${ }_{61}$ Zakon o lokalnoj i područnoj (regionalnoj) samoupravi, Official Gazette 33/2001, 60/2001, 125/2005, $109 / 2007,125 / 2008,36 / 2009,150 / 2011,144 / 2012,19 / 2013,137 / 2015$ and 123/2017 
fore, the aim of the local communities that have adopted the European Charter should be to design the modalities in which the legally binding obligation of at least $40 \%$ representation of both sexes in the election slates for local elections and consequently equitable representation of both sexes in representative bodies of local communities will be achieved. One of the most important steps is certainly access to political parties. All political parties represented in the local community should be required to commit themselves to empowering and encouraging women to participate more actively in party's political work. This requirement is already a significant step forward, since, as a rule, the party policies are defined at national, and rarely at the local level. Likewise, political parties foster the activities related to inclusion of women in politics predominantly at the national level. ${ }^{62}$ It is, thus, important to empower and encourage women at the local level to be more actively involved in the work of political parties by organizing additional campaigns and to promote their political function. In addition, political parties need to revise their nomination procedures and nomination for electoral slates in order to increase the level of representation of women in representative bodies and refer them to apply the so-called zipper system by which male and female candidates will be nominated alternately on electoral slates.

The local community must prompt political parties by the means of action plan for equality to building gender-aware party programmes, to imposing women's issues of local importance on the public, and to systematically empower and train women participating in political parties, as well as to motivate women's lobbying in representative bodies of local and regional self-government. Through this form of action plan for equality in the political sphere, the local community will undoubtedly improve the political status of women and bring them closer or even bring them to the goal of balanced or equal representation in representative bodies.

By the end of 2018 the European Charter was adopted only by three municipalities: Vela Luka, Punat, and Vižinada, twelve cities/towns: Opatija, Cres, Delnice, Zadar, Solin, Vodice, Vukovar, Osijek, Labin, Punat, Pregrada and Ludbreg and twelve counties: Brod-Posavina, Varaždin, Vukovar-Srijem, Virovitica-Podravina, Bjelovar-Bilogora, Istra, Dubrovnik-Neretva, Šibenik-Knin, Primorje-Gorski Kotar, Zagreb, Međimurje and Krapina-Zagorje Counties. ${ }^{63}$ According to the data

62 Barburska, O., Political Party Strategies for Increased Representation of Women in Political Decision-Making in the EU Member States and Poland, Yearbook of Polish European Studies, Vol. 6, 2002, pp. 133152

63 Data available on: [https://ravnopravnost.gov.hr/institucionalni-mehanizmi-1639/europska-povelja-o-ravnopravnosti-zena-i-muskaraca-na-lokalnoj-razini/provedba-europske-povelje-o-ravnopravnosti-zena-i-muskaraca-na-lokalnoj-razini/3091/] Accessed 09.04.2019 
of the Ministry of Administration of the Republic of Croatia ${ }^{64}$ and the Statistical Yearbook $2018^{65}$ a total of 576 local and regional self-government units were established in the Republic of Croatia. As only 27 units of local and regional self-government in the Republic of Croatia adopted the European Charter, i.e. only $4.7 \%$, which gives a serious cause for concern. The Gender Equality Ombudsperson's report for 2017 stated that for the purpose of a clear commitment to respecting the principle of gender equality in the area of political participation at the local level all local and regional self-government units in the Republic of Croatia are recommended each year to sign the European Charter. However, the question remains why only a minority of local and regional self-government units in the Republic of Croatia adopted the European Charter. Is it because the topic of equality of women and men is not interesting enough or is it that political actors in local communities do not truly wish women were more represented in political decision-making.

Besides a small number of local and regional self-government units that adopted the European Charter, it should be pointed out that, according to the information available to the author of the paper, none of the local or regional self-government units in the Republic of Croatia has yet drawn up an action plan for equality. The aforementioned situation is a matter of concern, since the European Charter commits the signatories to drafting and adopting an action plan for equality within a reasonable time, but not exceeding two years after signing the European Charter, and this deadline has already expired in the Republic of Croatia. Due to such conduct on behalf of the signatories, a conclusion can be drawn that they had only formally agreed to sign the European Charter without any real intention of improving and achieving equality between women and men in everyday life in local communities.

The expectations were that such an important international instrument as the European Charter, would be more publicized among local and regional self-government units. Since this has not been the case, we can say that the European Charter in the Republic of Croatia, although adopted thirteen years ago, has not survived. Therefore, additional activities will be required to inform the entire Croatian public, especially political participants and the non-governmental sector, of the benefits and values that the European Charter promotes. This can be done through the systematic promotion of the European Charter by means of

\footnotetext{
64 Data available on: [https://uprava.gov.hr/o-ministarstvu/ustrojstvo/5-uprava-za-politicki-sustav-i-organizaciju-uprave-1075/lokalna-i-podrucna-regionalna-samouprava/popis-zupanija-gradova-i-opcina/846/] Accessed 15.04.2019

65 Statistički ljetopis 2018, Državni zavod za statistiku RH, Zagreb, 2018, p. 59
} 
public communication, and in particular, by organizing gender equality training and public discussions that would make the public aware that disseminating and implementing the Charter will advance the equality of women and men in all areas of life in local communities.

\section{RESEARCH INTO THE RESULTS OF LOCAL ELECTIONS HELD IN FOUR ROUNDS IN THE REPUBLIC OF CROATIA}

Participation of women in the implementation of public policies at local and regional level provides insight into women's life experiences, personality, ability, education and creativity and it contributes to the development of local society. If we want to create a society based on equality and respect for all groups in the society, it is an imperative that local authorities accept the aspect of sex when planning and introducing strategies in managing their units as well as in everyday life practice. Having noted the above, the author decided to research and analyze the issue of representation of women and men in representative bodies of local and regional self-government in the Republic of Croatia.

This section deals with the results of the research conducted into the local elections data in the last four election rounds aimed at determining the level of implementation of the gender equality principle in the area of political participation at local and regional level, i.e. in city councils and county assemblies in all counties of the Republic of Croatia.

\subsection{Methodology and Research Objectives}

The hypothesis set to this research is that existing legal and institutional mechanisms are not sufficient to achieve a balanced representation of both sexes in representative bodies of local authorities. The research was conducted into the local elections data in the election years of 2005, 2009, 2013 and 2017. The statistics are derived from secondary sources and represent the local elections results officially pronounced by the State Election Commission of the Republic of Croatia and statistical data published by the Central Bureau of Statistics of the Republic of Croatia on their official web sites, as well as the data published on the official web site of the Ombudswoman for Gender Equality. The results have been analyzed by means of comparative analysis, while the descriptive statistics used in the paper has provided a description, comparison and analysis based on the presentation and statistical data processing; data editing, tabular and graphical presentations have been applied. The aim of the research was to determine, by observing the principle of gender equality, whether the results of local elections in the aforementioned 
election rounds are data representing the existing (un)successful legal and institutional framework in the Republic of Croatia.

\subsection{Research results}

\subsubsection{Local elections held in the Republic of Croatia in 2005}

Table 1: Elected Representatives in Representative Bodies of Local and Regional Self-Government by Counties in the Republic of Croatia at Local Elections in 2005

\begin{tabular}{|l|c|c|}
\hline COUNTY & $\begin{array}{c}\text { ELECTED REPRESENTA- } \\
\text { TIVES IN CITY COUNCILS } \\
\text { IN PERCENTAGE }\end{array}$ & $\begin{array}{c}\text { ELECTED REPRESENTA- } \\
\text { TIVES IN COUNTY ASSEM- } \\
\text { BLIES IN PERCENTAGE }\end{array}$ \\
\hline Zagreb & 14.6 & 26.7 \\
\hline Krapina-Zagorje & 7.5 & 13.7 \\
\hline Sisak-Moslavina & 14.8 & 18.4 \\
\hline Karlovac & 8.0 & 14.6 \\
\hline Varaždin & 17.9 & 4.9 \\
\hline Koprivnica-Križevci & $\mathbf{2 8 . 9}$ & 19.5 \\
\hline Bjelovar-Bilogora & 17.6 & 14.6 \\
\hline Primorje-Gorski Kotar & 15.2 & 14.6 \\
\hline Lika-Senj & 12.1 & 6.7 \\
\hline Virovitica-Podravina & 20.8 & 9.8 \\
\hline Požega-Slavonija & 10.9 & 14.3 \\
\hline Brod-Posavina & 15.9 & 15.7 \\
\hline Zadar & 12.7 & 12.2 \\
\hline Osijek-Baranja & 11.9 & 8.5 \\
\hline Šibenik-Knin & 11.5 & $\mathbf{2 . 4}$ \\
\hline Vukovar-Srijem & 10.2 & 9.8 \\
\hline Split-Dalmatia & 12.4 & 7.8 \\
\hline Istra & 21.1 & $\mathbf{2 6 . 8}$ \\
\hline Dubrovnik-Neretva & 10.8 & 7.3 \\
\hline Međimurje & 26.3 & $\mathbf{2 6 . 8}$ \\
\hline The City of Zagreb & 27.5 & 27.5 \\
\hline TOTAL & 15.7 & 14.5 \\
\hline DOta soure & & 14.5 \\
\hline
\end{tabular}

Data source on elected representatives in county assemblies: Croatian Central Bureau of Statistics, Women and Men in Croatia 2006, Zagreb, 2006, p. 74. Data source on elected representatives in city councils: Elections for Representatives of Representative Bodies of Local and Regional Self-Government (May 15, 2005), Gender Equality Ombudsperson, Zagreb, December 2005; available at: [http:/l www.prs.hrlattachments/article/130/LOKALNI\%20IZBORI\%202005.pdfI] 
According to the 2005 local elections data, the average representation of women as elected representatives in all city councils in the Republic of Croatia amounts to $15.7 \%$, and in the county assemblies to $14.5 \%$.
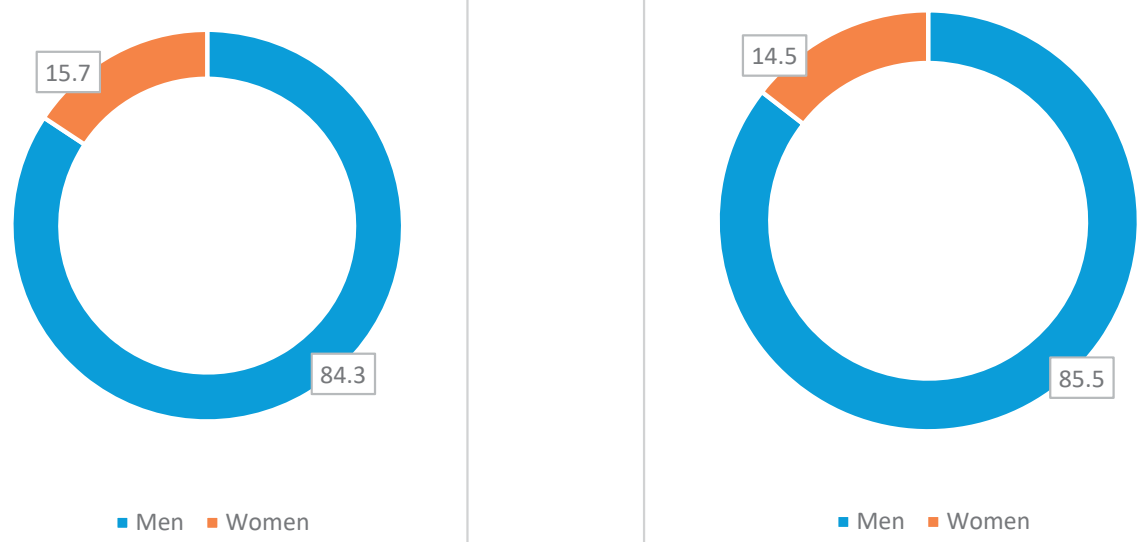

Women are most represented in the city councils of Koprivnica-Križevci County (28.9\%) and in county assemblies of Istra County and Medimurje County (26.8\%), whereas they are the most underrepresented in city councils of Krapina-Zagorje County $(7.5 \%)$ and in the county assembly of Šibenik-Knin County (2.4\%).

\subsubsection{Local elections held in the Republic of Croatia in 2009}

Table 2: Elected Representatives in Representative Bodies of Local and Regional Self-Government by Counties in the Republic of Croatia at Local Elections in 2009

\begin{tabular}{|l|c|c|}
\hline COUNTY & $\begin{array}{c}\text { ELECTED REPRESENTA- } \\
\text { TIVES IN CITY COUNCILS } \\
\text { IN PERCENTAGE }\end{array}$ & $\begin{array}{c}\text { ELECTED REPRESENTATIVES } \\
\text { IN COUNTY ASSEMBLIES IN } \\
\text { PERCENTAGE }\end{array}$ \\
\hline Zagreb & 20.9 & 33.3 \\
\hline Krapina-Zagorje & $\mathbf{9 . 2}$ & 20.0 \\
\hline Sisak-Moslavina & 19.5 & 24.5 \\
\hline Karlovac & 25.3 & 19.5 \\
\hline
\end{tabular}

Figure 1. Average representation of women, elected representatives in city councils in the Republic of Croatia (local elections 2005)
Figure 2. Average representation of women, elected representatives in county assemblies in in the Republic of Croatia (local elections 2005) 


\begin{tabular}{|l|c|c|}
\hline Varaždin & 19.6 & 22.0 \\
\hline Koprivnica-Križevci & $\mathbf{3 0 . 5}$ & 26.8 \\
\hline Bjelova-Bilogora & 26.4 & $\mathbf{1 2 . 2}$ \\
\hline Primorje-Gorski Kotar & 20.7 & 22.0 \\
\hline Lika-Senj & 16.7 & 22.2 \\
\hline Virovitica-Podravina & 18.9 & 14.6 \\
\hline Požega-Slavonija & 17.3 & 19.5 \\
\hline Brod-Posavina & 25.0 & 27.5 \\
\hline Zadar & 18.6 & 24.4 \\
\hline Osijek-Baranja & 19.3 & 12.8 \\
\hline Šibenik-Knin & 18.8 & 17.1 \\
\hline Vukovar-Srijem & 25.0 & 14.6 \\
\hline Split-Dalmatia & 18.8 & 19.6 \\
\hline Istra & 28.8 & 26.8 \\
\hline Dubrovnik-Neretva & 20.5 & 19.5 \\
\hline Međimurje & 18.9 & 22.0 \\
\hline City of Zagreb & 26.1 & $\mathbf{3 5 . 3}$ \\
\hline Total & 21.4 & 21.9 \\
\hline
\end{tabular}

Source: Croatian Central Bureau of Statistics, Women and Men in Croatia in 2010, Zagreb, 2010, pp. 61-62.

According to the data on local elections held in 2009, the average representation of women as elected representatives in all city councils in the Republic of Croatia is $21.4 \%$, and in county assemblies $21.9 \%$.

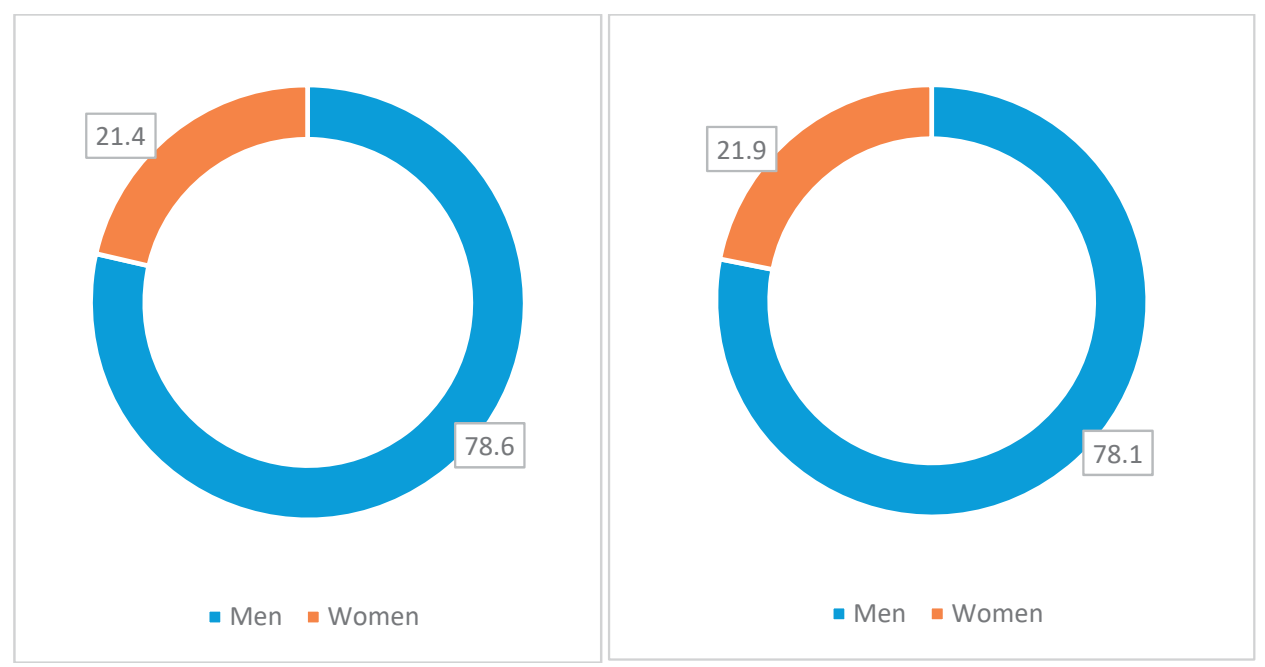


Figure 3. Average representation of Figure 4. Average representation of womwomen, elected representatives in en, elected representatives in county ascity councils in the Republic of Cro- semblies in the Republic of Croatia (local atia (local elections 2009) elections 2009)

Women are most represented in the city councils of Koprivnica-Križevci County (30.5\%) and the county assembly of the City of Zagreb (35.3\%), and they are the most underrepresented in the city councils of Krapina-Zagorje County (9.2\%) and in the county assembly of Bjelovar-Bilogora County (12.2\%).

\subsubsection{Local elections held in the Republic of Croatia in 2013}

Table 3: Elected Representatives in Representative Bodies of Local and Regional Self-Government by Counties in the Republic of Croatia at Local Elections in 2013

\begin{tabular}{|l|c|c|}
\hline COUNTY & $\begin{array}{c}\text { ELECTED REPRESENTA- } \\
\text { TIVES IN CITY COUNCILS } \\
\text { IN PERCENTAGE }\end{array}$ & $\begin{array}{c}\text { ELECTED REPRESENTATIVES } \\
\text { IN COUNTY ASSEMBLIES IN } \\
\text { PERCENTAGE }\end{array}$ \\
\hline Zagreb & 18.4 & 19.6 \\
\hline Krapina-Zagorje & 18.1 & 26.8 \\
\hline Sisak-Moslavina & 22.6 & $\mathbf{1 4 . 0}$ \\
\hline Karlovac & 26.4 & 16.3 \\
\hline Varaždin & 22.1 & 31.7 \\
\hline Koprivnica-Križevci & $\mathbf{3 3 . 3}$ & 17.1 \\
\hline Bjelovar-Bilogora & 27.2 & 14.6 \\
\hline Primorje-Gorski Kotar & 23.0 & 26.7 \\
\hline Lika-Senj & 23.0 & 18.8 \\
\hline Virovitica-Podravina & 22.2 & 16.7 \\
\hline Požega-Slavonija & 18.6 & 22.2 \\
\hline Brod-Posavina & 26.2 & 19.0 \\
\hline Zadar & 18.6 & 10.0 \\
\hline Osijek-Baranja & $\mathbf{1 7 . 7}$ & 16.4 \\
\hline Šibenik-Knin & 20.5 & 16.7 \\
\hline Vukovar-Srijem & 23.5 & $\mathbf{1 4 . 0}$ \\
\hline Split-Dalmatia & 24.9 & 21.6 \\
\hline Istra & 30.4 & 35.6 \\
\hline Dubrovnik-Neretva & 26.4 & 17.1 \\
\hline Međimurje & 23.5 & 21.4 \\
\hline City of Zagreb & 24.7 & 20.7 \\
\hline TOTAL & 23.3 & \\
\hline
\end{tabular}

Source: Central Bureau of Statistics of the Republic of Croatia, Women and Men in Croatia in 2014, Zagreb, 2014, pp. 69-70. 
According to the data of the local elections held in 2013 the average representation of women as elected representatives in all city councils in the Republic of Croatia is $23.3 \%$, and in county assemblies $20.7 \%$.

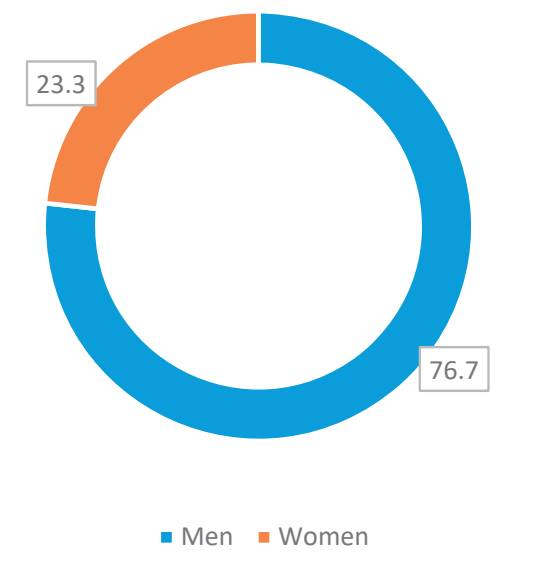

Figure 5. Average representation of Figure 6. Average representation of women, elected representatives in city councils in the Republic of Croatia (local elections 2013)

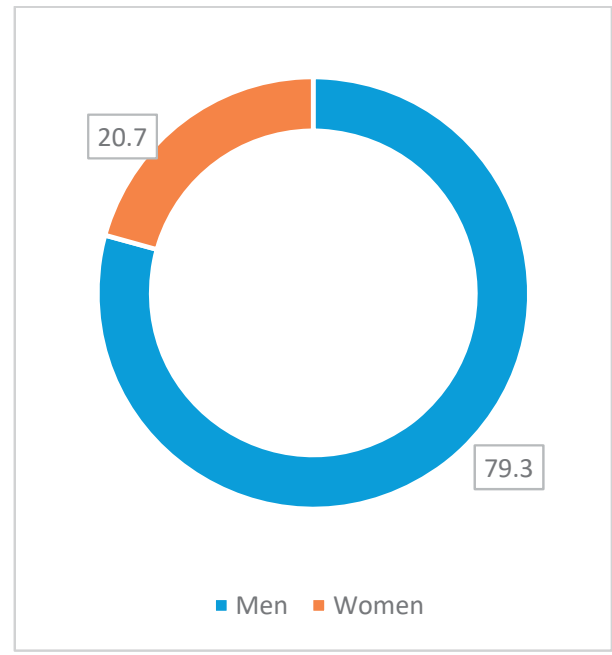

women, elected representatives in county assemblies in the Republic of Croatia (local elections 2013)

Women are most represented in the city councils of Koprivnica-Križevci County (33.3\%) and the county assembly of the City of Zagreb County (35.3\%), and they are the most underrepresented in the city councils of Osijek-Baranja County (17.7\%) and in the county assemblies of Sisak-Moslavina and Vukovar-Srijem County (14\%).

\subsubsection{Local elections held in the Republic of Croatia in 2017}

Table 4: Elected Representatives in Representative Bodies of Local and Regional Self-Government by Counties in the Republic of Croatia at Local Elections in 2017

\begin{tabular}{|l|c|c|}
\hline COUNTY & $\begin{array}{c}\text { ELECTED REPRESENTA- } \\
\text { TIVES IN CITY COUNCILS } \\
\text { IN PERCENTAGE }\end{array}$ & $\begin{array}{c}\text { ELECTED REPRESENTATIVES } \\
\text { IN COUNTY ASSEMBLIES IN } \\
\text { PERCENTAGE }\end{array}$ \\
\hline Zagreb & 21.2 & 27.5 \\
\hline Krapina-Zagorje & 28.6 & 36.6 \\
\hline Sisak-Moslavina & 28.4 & 19.0 \\
\hline Karlovac & 25.6 & 29.3 \\
\hline Varaždin & $\mathbf{1 8 . 1}$ & 29.3 \\
\hline
\end{tabular}




\begin{tabular}{|l|l|l|}
\hline Koprivnica-Križevci & 24.6 & 19.5 \\
\hline Bjelovar-Bilogora & 32.2 & 24.4 \\
\hline Primorje-Gorski Kotar & 27.4 & 32.6 \\
\hline Lika-Senj & 27.9 & 18.7 \\
\hline Virovitica-Podravina & 35.2 & 29.7 \\
\hline Požega-Slavonija & 29.8 & 21.6 \\
\hline Brod-Posavina & $\mathbf{3 8 . 1}$ & 35.7 \\
\hline Zadar & 25.5 & 33.3 \\
\hline Osijek-Baranja & 23.2 & 16.4 \\
\hline Šibenik-Knin & 31.0 & 33.3 \\
\hline Vukovar-Srijem & 26.0 & 18.6 \\
\hline Split-Dalmatia & 23.4 & $\mathbf{1 3 . 7}$ \\
\hline Istra & 36.7 & 37.8 \\
\hline Dubrovnik-Neretva & 23.0 & 24.4 \\
\hline Međimurje & 23.5 & 23.8 \\
\hline City of Zagreb & 29.4 & $\mathbf{3 9 . 2}$ \\
\hline TOTAL & 27.1 & 26.9 \\
\hline
\end{tabular}

Source: Central Bureau of Statistics of the Republic of Croatia, Women and Men in Croatia 2017, Zagreb, 2017, pp. 75-76.

According to the data of the local elections held in 2017 the average representation of women as elected representatives in all city councils in the Republic of Croatia is $27.1 \%$, and in county assemblies $26.9 \%$.
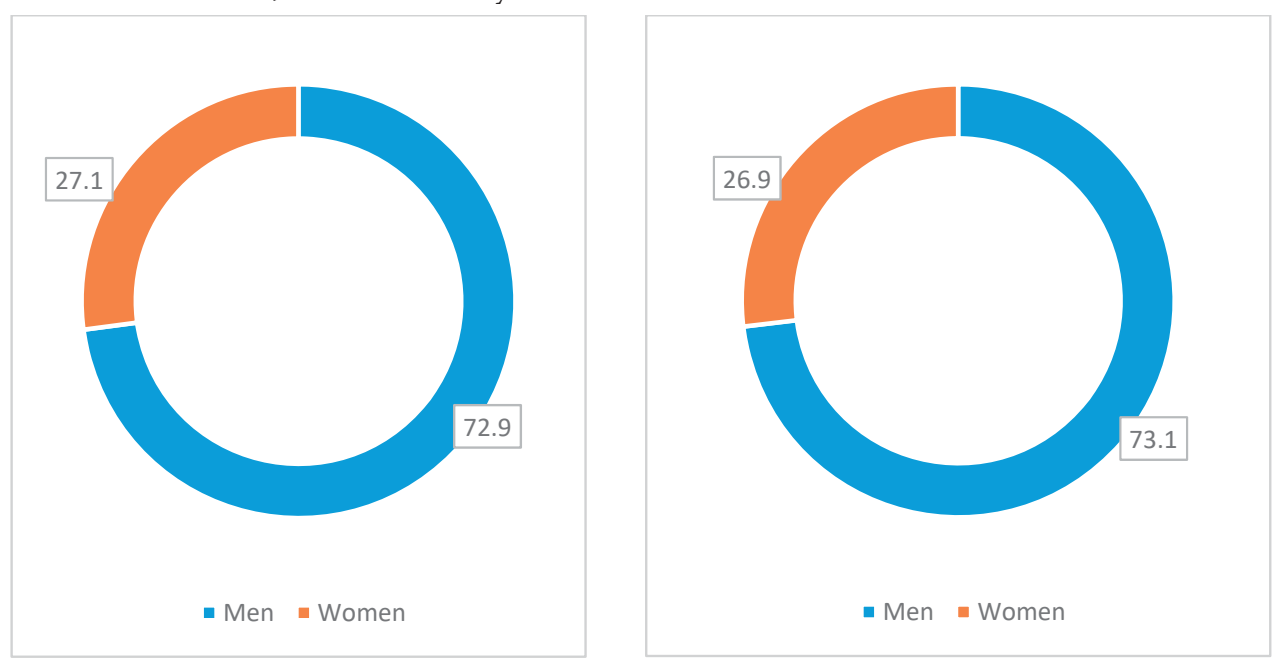
Figure 7. Average representation of women, elected representatives in city councils in the Republic of Croatia (local elections 2017)
Figure 8. Average representation of women, elected representatives in county assemblies in the Republic of Croatia (local elections 2017)

Women are most represented in the city councils of Brod-Posavina County (38.1\%) and in the county assembly of the City of Zagreb County (39.2\%), and they are the most underrepresented in the city council of Varaždin County (18.1\%) and in the county assembly of Split-Dalmatia County (13.7\%).

The Gender Equality Ombudswoman's Report for 2017 shows that at the local elections in 2017, women (albeit) were not a significantly underrepresented sex in the candidacy procedure - out of a total of 47,601 candidates there were $41.7 \%$ women, which was a direct consequence of observance of the principle of gender equality in terms of the gender quota set to at least $40 \%$ of one sex on a candidate list. The quota was not observed in as many as $14 \%$ of the candidate lists. However, in spite of this quite favourable quantitative representation on the candidate lists, other forms of inequality still exist. Women were most represented in lower positions on the lists, with only $15 \%$ of women among the list holders.

\subsection{Overall results}

The results of local elections held in 2005, 2009, 2013 and 2017 are presented in Table 5.

Table 5: Overview of representatives in city councils and county assemblies according to years of local elections

\begin{tabular}{|l|l|l|l|l|}
\hline \multirow{2}{*}{ Election year } & \multicolumn{2}{|l|}{ representatives in city councils } & \multicolumn{2}{l|}{ representatives in county assemblies } \\
\cline { 2 - 5 } & $\begin{array}{l}\text { average rep- } \\
\text { resentation }\end{array}$ & $\begin{array}{l}\text { Increase/decrease in } \\
\text { relation to the last local } \\
\text { elections }\end{array}$ & $\begin{array}{l}\text { average rep- } \\
\text { resentation }\end{array}$ & $\begin{array}{l}\text { Increase/decrease in } \\
\text { relation to the last } \\
\text { local elections }\end{array}$ \\
\hline 2005 & $15.7 \%$ & & $14.5 \%$ & \\
\hline 2009 & $21.4 \%$ & $+5.7 \%$ & $21.9 \%$ & $+7.4 \%$ \\
\hline 2013 & $23.3 \%$ & $+1.9 \%$ & $20.7 \%$ & $-1.2 \%$ \\
\hline 2017 & $27.1 \%$ & $+3.8 \%$ & $26.9 \%$ & $+6.2 \%$ \\
\hline
\end{tabular}

The average representation of all elected representatives in 2005 local elections in city councils in the Republic of Croatia was $15.7 \%$, and in the county assemblies $14.5 \%$. In local elections held in 2009 in urban councils, the average representation of women was $21.4 \%$, and in county assemblies $21.9 \%$. In the elections held in 2013 , the average representation of women in city councils was $23.3 \%$, and in county assemblies $20.7 \%$, while in local elections held in 2017 , the average 
representation of women in city councils was $27.1 \%$, and in county assemblies it amounted to $26.9 \%$.

The results of the research show that women participation in representative bodies of local and regional self-government is very low, that some progress has been made in local elections in 2009 compared to elected women representatives in local elections in 2005, when the ratio of participation of women representatives in city councils increased by $5.7 \%$ (from $15.7 \%$ to $21.4 \%$ ) and that of female representatives in county assemblies increased by $7.4 \%$ (from $14.5 \%$ to $21.9 \%$ ). In the following electoral round of local elections held in 2013, there was a slight increase in the number of elected women representatives in city councils by $1.9 \%$ (from $21.4 \%$ to $23.3 \%$ ), but also a slight decrease in the number of elected women representatives in county assemblies by $1.2 \%$ (from $21.9 \%$ to $20.7 \%$ ). In the last electoral round of local elections held in 2017 , compared to the previous electoral round of local elections held in 2013, the expected results of equal representation of both sexes were apparently not achieved, as the participation of women representatives in city councils increased by only $3.8 \%$ (from $23.3 \%$ to $27.1 \%$ ), and the number of women representatives in county assemblies increased by only $6.2 \%$ (from $20.7 \%$ to $26.9 \%$ ) (Figure 9).

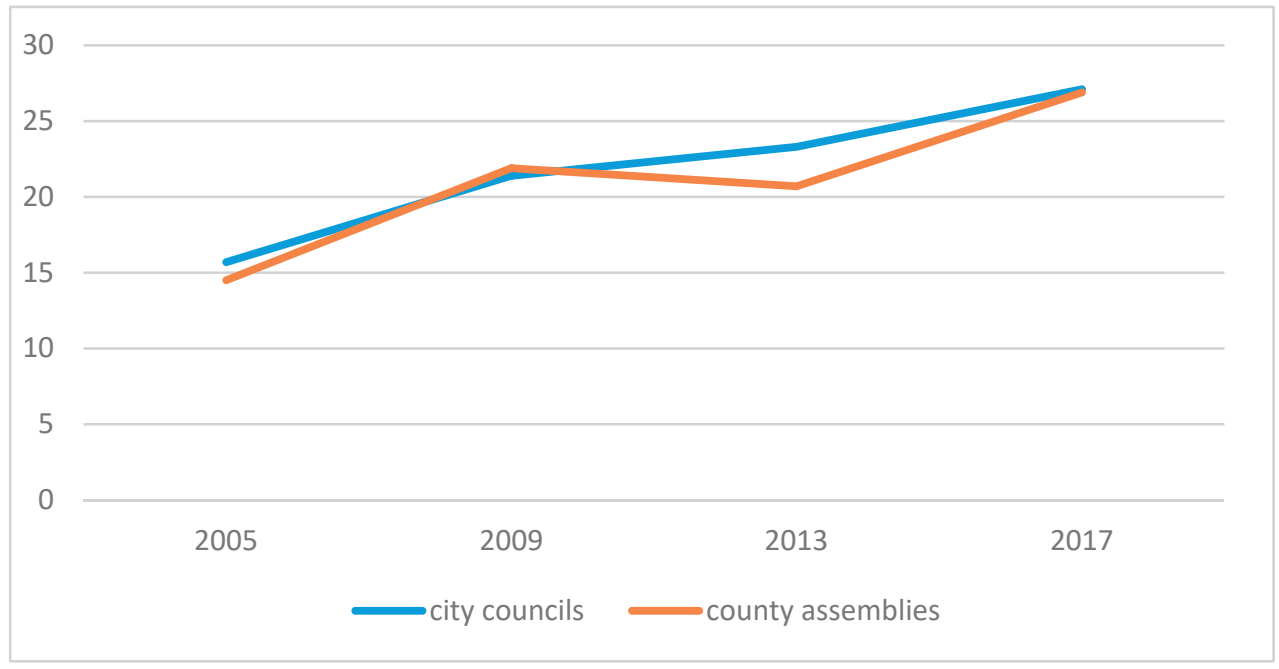

Figure 9. Comparative overview of the average representation of women in city councils and county assemblies of the Republic of Croatia according to the year of local elections

There is a tendency indicating a continuous but slow increase in the representation of women in city councils. At last local elections, women's representation in city 
councils was by $11.4 \%$ higher than in 2005 .

The increasing tendency of representation of women in county assemblies was briefly halted in 2013. At last local elections, the representation of women in county assemblies increased by $12.4 \%$ compared to 2005 .

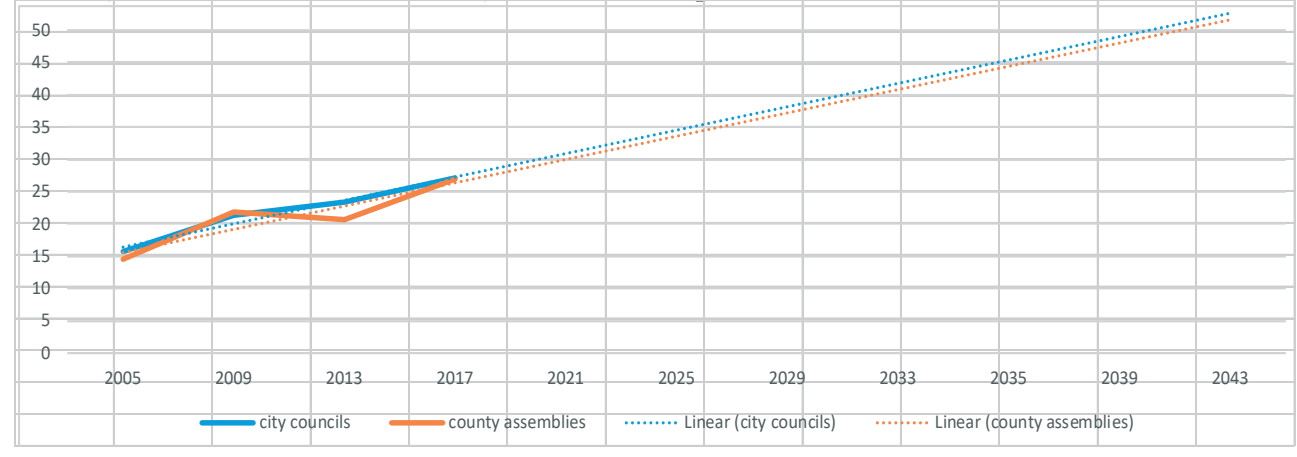

Figure 10. Comparative overview of gender equality achievement in city councils and county assemblies in the Republic of Croatia

The research results show that equality in representation of both sexes has not been achieved yet, as expected by the implementation of the Gender Equality Act (2008). Pursuant to Article 15 paragraph 2 of the Gender Equality Act (2008) a gradual increase in representation of under-represented sex is allowed but equality must be achieved at the latest upon the implementation of the third regular elections since the entry into force of the Gender Equality Act (2008), which should have been the case at the local elections held in $2017 .{ }^{66}$ If social and political circumstances do not significantly change, and if new tools for increasing women's representation are not applied, this slow dynamics of women's representation increase in reaching a balanced representation of at least $40 \%$ of both sexes in representative local and regional bodies may only be expected in the elections held in 2033, i.e. after four regular electoral rounds, while accomplishment of true equality of both sexes shall still remain a difficult goal.

\section{CONCLUSION}

Despite the fact that gender equality is set as one of the constitutional values in the Republic of Croatia and that according to the Gender Equality Act (2008) it means that women and men are equally present in all areas of public and private life, as regards political participation at a local level women are still a considerably

66 See more on this topic in: Lulić, M.; Tucak, I.: Women and politics: the ineffectiveness of electoral gender quotas for parliamentary elections in the Republic of Croatia, SGEM2017 Conference Proceedings 2017, Book 1, Vol. 2, pp. 307-320 
underrepresented sex. The research results in this paper indicate that the average (political) representation is far below equitable representation of both sexes in representative bodies of local authorities.

It is beyond question that the aim and the purpose of all pieces of legislation listed in this paper is to achieve full equality and not to just normatively regulate the issue of representation of women. The set standards should have demonstrated some results by now. However, the results have been missing on multiple occasions and for a long time. Finally, the conclusion may be drawn that the legal and institutional mechanisms aimed at providing for gender equality have not achieved their goal, and obviously, local communities will have to seize for other tools in order to attempt to achieve full equality.

In the Republic of Croatia, local and regional self-government units are founded on the principle of autonomy of the authorities, which entitles them to independent management based on regulations that they independently pass as well as on the principle of subsidiarity, according to which the level of government closest to the citizens is entrusted with decision making and implementation. Taking the aforementioned circumstance into consideration, additional activities in the local community can considerably raise awareness among citizens and political actors of the need to increase the number of women in the representative bodies of local and regional self-government units. This can be done, in the first place, by recognizing the European Charter as a serious platform to which a number of positive actions can be upgraded in order to raise the awareness of the broader public. The effectiveness of the measures to be adopted by the action plan for equality will primarily depend on the inventiveness, skillfulness, understanding and creativity of the body in charge of its development. It is, therefore, necessary to strongly and skillfully present the European Charter to every local and regional authority, as well as to the general public, to highlight its scope and potential, and to point out its benefits for the local community. Furthermore, in order to achieve the goal set by the European Charter i.e. the equality of women and men at the local level, and to increase the political role of women in local communities as discussed in this paper, it is important to plan and work out the methods for motivating citizens and political parties to actions that will lead to substantial increase in representation of women, so that no action plan for equality remains just a dead letter on the paper, which was the case with the Gender Equality Act (2008) when it comes to equal representation of both sexes in representative bodies.

The European Charter makes it possible to strengthen the social and political environment supporting the equality of both sexes, as one of the foundations of the development of modern democracy. For this reason, local communities are recommended to draw up, based on the European Charter, functional action plans 
for achieving equality meeting their own priorities; to use the European Charter for training the public, both civil and political through forums, roundtables, public presentations and debates, media campaign and to raise awareness about the importance of gender equality and to provide the public with feedback on state of affairs, and above all to point to the legal obligation of its improvements. The local communities are entrusted with the task to apply the available tools for activation of (political) potentials in women, but also for making the public aware of the issue and, thus improve the quality of their representative bodies and achieve a truly equitable and democratic society.

\section{REFERENCES}

\section{BOOKS AND ARTICLES}

1. Barburska, O., Political Party Strategies for Increased Representation of Women in Political Decision-Making in the EU Member States and Poland, Yearbook of Polish European Studies, Vol. 6, 2002

2. Chandler, J.A., Local Government Today, Third edition, Manchester University Press, 2001, pp. 100-116

3. Craig, P., de Burca, G., EU Law, Text, Cases and Materials, Fifth edition, Oxford, University press, 2011

4. Dahlerup, D., Women, Quotas and Politics, Routledge research in comparative politics, Routledge, London and New York, 2006

5. Diaz, M.M., Representing Women?: Female Legislators in West European Parliaments, ECPR Press, 2005

6. Freedman, J. 2002: Women in the European Parliament, in: Women, Politics and Change, Oxford University Press, New York, 2002

7. Gardašević, Đ., Ljudska prava i temeljne slobode u Ustavu RH, in: Ljudska prava, Pravni fakultet Sveučilišta u Zagrebu, Zagreb, 2014

8. Hayes, D., Lawless, J.L., Women on the Run: Gender, Media, and Political Campaigns in a Polarized Era, Cambridge University Press, 2016

9. Hughes, M.M., Intersectionality, Quotas and Minority Women's Political Representation Worldwide, The American Political Science Review, Vol. 105, 2011

10. Kenworthy, L., Malami, M., Gender Inequality in Political Representation: A Worldwide Comparative Analysis, the University of North Carolina Press, Social Forces, Vol. 78, No. 1, 1999

11. Kunovich, S., Paxton, P., Pathways to Power: The Role of Political Parties in Women's National Political Representation, American Journal of Sociology, Vol. 111, No 2, 2005

12. Leinert Novosel, S., Percepcija, iskustvo i stavovi o rodnoj (ne)ravnopravnosti u politici, u: Rodna ravnopravnost i diskriminacija u Hrvatskoj, Istraživanje, Percepcija, iskustva i stavovi o rodnoj diskriminaciji u Republici Hrvatskoj, Zagreb, Biblioteka ONA, 2011

13. Leinert Novosel, S., Rodni stereotipi, predrasude i diskriminacija žena u politici, Ljudska prava žena, Institut društvenih znanosti Ivo Pilar, Zagreb, 2011 
14. Leinert Novosel, S., Žena na pragu 21. stoljeća-između majčinstva i profesije, TOD i EDAC, Zagreb, 1999

15. Leinert Novosel, S., Politika ravnopravnosti spolova: kako do „kritične mase“žena u parlamentima?, Politička misao, Vol. XLIV, No. 3, 2007

16. Lovenduski, J., State Feminism and Political Representation, Cambridge University Press, 2005

17. Lulic, M.; Tucak, I.: Women and politics: the ineffectivness of electoral gender quotas for parliamentary elections in the Republic of Croatia, SGEM2017 Conference Proceedings, Book 1, Vol 2, 2017

18. Mansbridge, J., Quota Problems: Combating the Dangers of Essentialism, u: Politics \& Gender 1, No. 4, 2005.

19. Norris, P., Electoral Engineering, Voting, Rules and Political Behavior, Cambridge, Cambridge University Press, 2004

20. Norris, P., Passagess to Power: Legislative Recruitment in Advanced Democraties, Cambridge University Press, Cambridge, 1997

21. Omejec, J., Vijeće Europe i Europska Unija, Institucionalni i pravni okvir, Novi informator, Zagreb, 2008

22. Ortenblad, A.; Marling, R.; Vasiljević, S., Gender Equality in a Global Perspective, Routledge, 2017

23. Paxton, P.; Hughes, M.M.; Painter, M.A.II., Growth in Women's Political Representation: A Longitudinal Exploration of Democracy, Electoral System and Gender Quotas, Center for the Study of Democracy, UC Irvine, 2009

24. Rodin, S., Jednakost muškarca $i$ žene, Pravo i politika u EU i Hrvatskoj, Institut za međunarodne odnose - IMO, Zagreb, 2003

25. Rodin, S., Vasiljević, S. Zakon o ravnopravnosti spolova, Revija za socijalnu politiku, Vol. 10, No. 3, 2003

26. Sawer, M., Equal opportunities, in: Kramarae; Cheris/Spender; Dale (eds.), International Encyclopedia of Women. Global Women Issues and Knowledge, Routledge, Routledge, London/New York, 2000

27. Sawer, M.; Tremblay, M.; Trimble, L., Representing Women in Parliament: A Comparative Study, Routledge, 2006

28. Shvedova, N., Obstacles to Women's Participation in Parliament, Women in Parliament: Beyond Numbers, International IDEA, Stockholm, 2005

29. Sineau, M., Ravnopravnost - Vijeće Europe i sudjelovanje žena u političkom životu, Vijeće Europe, 2003

30. Šinko, M., Žene u parlamentima - globalna perspektiva, Politička misao, Vol. XLIV, No.2, 2007

31. Sledzinska-Simon, A., Gender Quotas and Women Solidarity as a Challenge to the Gender Regime in Poland, in: Lepinard, E.; Rubio-Marin, R. (eds.), Transforming Gender Citizenship, Cambridge University Press 2018

32. Statistički ljetopis 2018, Državni zavod za statistiku RH, Zagreb, 2018 
33. Suk, J.C., Gender Quotas after End of Men, Boston University Law Review Vol. 93, 2013

34. Tremblay, M., Women and Legislative Representation: Electoral Systems, Political Parties and Sex Quotas, Palgrave Macmillan, 2012

35. Vandenbeld, A., The Oxford Handbook of Transnational Movements, International Trends in Women's Political Participation, Oxford University Press, 2015

36. Vasiljević, S., Neka se čuje $i$ druga strana: primjeri spolne i etničke diskriminacije, Centar za ženske studije, Zagreb, 2012

37. Vasiljević, S., Slično i različito - Diskriminacija u Europskoj uniji i Republici Hrvatskoj, TIMpress, Zagreb, 2011

38. Žene i muškarci u Hrvatskoj 2006, Državni zavod za statistiku RH, Zagreb, 2006

39. Žene i muškarci u Hrvatskoj 2010, Državni zavod za statistiku RH, Zagreb, 2010

40. Žene i muškarci u Hrvatskoj 2014, Državni zavod za statistiku RH, Zagreb, 2014

41. Žene i muškarci u Hrvatskoj 2017, Državni zavod za statistiku RH, Zagreb, 2017

\section{NATIONAL REGULATIONS, ACTS AND COURT DECISIONS}

1. Ustav RH, Official Gazette, 56/1990, 135/1997, 8/1998, 113/2000, 124/2000, 28/2001, 41/2001, 55/2001, 76/2010, 85/2010, 05/2014

2. Zakon o ravnopravnosti spolova, Official Gazette, 82/2008, 69/2017

3. Zakon o suzbijanju diskriminacije, Official Gazette, 85/2008, 112/2012

4. Zakon o lokalnim izborima, Official Gazette, 144/2012, 121/2016

5. Zakon o političkim strankama, Official Gazette, 76/1993, 111/1996, 164/1998, 36/2001, 28./2006

6. Zakon o izboru zastupnika u Hrvatski Sabor, Official Gazette, 116/1999, 109/2000, 53/2003, 69/2003, 167/2003, 44/2006, 19/2007, 20/2009,145/2010, 24/2011, 93/2011,120/2011, $19 / 2015,104 / 2015$

7. Zakon o lokalnoj i područnoj (regionalnoj) samoupravi, Official Gazette, 33/2001, 60/2001, $125 / 2005$, 109/2007, 125/2008, 36/2009, 150/2011,144/2012, 19/2013, 137/2015, $123 / 2017$

8. Odluka Ustavnog suda Republike Hrvatske broj: U-I-2696/2003 of 16 January 2008

9. Uredba o uredu za ravnopravnost spolova, Official Gazette, 39/2012

10. Nacionalna politika za promicanje ravnopravnosti spolova za razdoblje 2001-2005, Official Gazette, 112/2001

11. Nacionalna politika za promicanje ravnopravnosti spolova za razdoblje 2006-2010, Official Gazette, 114/2006

12. Nacionalna politika za promicanje ravnopravnosti spolova za razdoblje 2011-2015, Official Gazette, 88/2011

13. Opća deklaracija o ljudskim pravima, Official Gazette - International Agreements, No. $12 / 2009$

14. Povelja Ujedinjenih naroda, Official Gazette - International Agreements, No. 15/1993 and $7 / 1994$ 
15. Konvencija o političkim pravima žena, Službeni list FNRJ, Međunarodni ugovori i drugi sporazumi, No. 7/1954, the Republic of Croatia is a party to this Convention according to the Decision on publishing of multilateral treaties that the Republic of Croatia is a signatory to based on the succession notification, Official Gazette - International Agreements, No. $12 / 1993$

16. Međunarodni pakt o građanskim i političkim pravima, Službeni list SFRJ, No. 7/1971, the Republic of Croatia is a party to this Covenant according to the Decision on publishing of multilateral treaties that the Republic of Croatia is a signatory to based on the succession notification, Official Gazette - International Agreements, No. 12/1993

17. Međunarodni pakt o ekonomskim, socijalnim i kulturnim pravima, Službeni list SFRJ, No. 7/1971, the Republic of Croatia is a party to this Covenant according to the Decision on publishing of multilateral treaties that the Republic of Croatia is a signatory to based on the succession notification, Official Gazette - International Agreements, No. 12/1993

18. Konvencija o uklanjanju svih oblika diskriminacije protiv žena, Službeni list SFRJ, Međunarodni ugovori No. 11/1981, the Republic of Croatia is a party to this Convention according to the Decision on publishing of multilateral treaties that the Republic of Croatia is a signatory to based on the succession notification, Official Gazette - International Agreements, No. 12/1993

19. Fakultativni protokol uz Konvenciju o eliminaciji svih oblika diskriminacije protiv žena, Official Gazette - International Agreements, No. 3/2001 and 4/2001

20. Konvencija Vijeća Europe o sprječavanju i borbi protiv nasilja nad ženama i obiteljskog nasilja, Official Gazette - International Agreements, No. 3/2018

21. Konvencija za zaštitu ljudskih prava i temeljnih sloboda i Protokoli No 1, 4, 6, 7, 12, 13 and 14, Official Gazette - International Agreements, No. 18/1997, 61/1999, 8/1999, 14/2002, $13 / 2003,9 / 2005,1 / 2006$ and $2 / 2010$

22. Europska socijalna povelja, Official Gazette - International Agreements, No. 15/2002 and $8 / 2003$

23. Konvencija Vijeća Europe o suzbijanju trgovanja ljudima, Official Gazette - International Agreements, No. 7/2007

24. Konvencija Vijeća Europe o zaštiti djece od seksualnog iskorištavanja i seksualnog zlostavljanja, Official Gazette - International Agreements, No. 11/2011

25. The European Charter for Equality of Women and Men in Local Life, Council of European Municipalities and Regions, CEMR's General Assembly, Innsbruck, 2006

\section{WEBSITE REFERENCES}

1. Gender Equality Strategy 2018-2023, [https://www.coe.int/en/web/genderequality/genderequality-strategy/] Accessed 15.04.2019

2. Odbor za ravnopravnost spolova Hrvatskog sabora, [https://ravnopravnost.gov.hr/institucionalni-mehanizmi-1639/odbor-za-ravnopravnost-spolova-hrvatskoga-sabora/2021/] Accessed 12.04.2019 
3. Vlada RH, Izvješće o radu Ureda za ravnopravnost spolova Vlade RH u 2017. god., [https:// vlada.gov.hr/UserDocsImages//2016/Sjednice/2018/11\%20studeni/125\%20sjednica $\% 20$ vRH//125\%20-\%2029.pdf/] Accessed 15.03.2019

4. [http://www.charter-equality.eu/the-charter/la-presidence-en.html/] Accessed 15.04.2019

5. Observatory European Charter for Equality of Women and Men in Local life, [http:// www.charter-equality.eu/atlas-of-signatories-of-the-charter/presentation.html/] Accessed 10.04.2019

6. Europska povelja o ravnopravnosti spolova na lokalnoj razini, Mostar, 2012. Godine, [http://www.charter-equality.eu/wp-content/uploads/2013/03/European-Charter-in-Croatian-HR2.pdf/] Accessed 02.04.2019

7. Europska povelja za ravnopravnost žena i muškaraca na lokalnoj razini, [https://ravnopravnost.gov.hr/institucionalni-mehanizmi-1639/europska-povelja-o-ravnopravnosti-zenai-muskaraca-na-lokalnoj-razini/3088/] Accessed 03.04.2019

8. [https://ravnopravnost.gov.hr/institucionalni-mehanizmi-1639/europska-povelja-o-ravnopravnosti-zena-i-muskaraca-na-lokalnoj-razini/provedba-europske-povelje-o-ravnopravnosti-zena-i-muskaraca-na-lokalnoj-razini/3091/] Accessed 11.04.2019

9. [https://uprava.gov.hr/o-ministarstvu/ustrojstvo/5-uprava-za-politicki-sustav-i-organizaciju-uprave-1075/lokalna-i-podrucna-regionalna-samouprava/popis-zupanija-gradova-i-opcina/846/] Accessed 15.04.2019

10. Izbori za članove/ice predstavničkih tijela jedinica lokalne i područne (regionalne) samouprave (15 May 2005), Pravobraniteljica za ravnopravnost spolova, Zagreb, December 2005, available at: [http://www.prs.hr/attachments/article/130/LOKALNI\%20IZBORI\%20 2005.pdf/] Accessed 15.04.2019 